\title{
Historical and Projected Distributions of Daily Temperature and Pressure in the Arctic
}

\author{
MICHAEL S. TIMLIN ${ }^{1,2}$ and JOHN E. WALSH ${ }^{1}$
}

\author{
(Received 20 November 2006; accepted in revised form 1 May 2007)
}

\begin{abstract}
Changes in extreme temperatures and pressures in the Arctic have received little attention in the context of climate change. Here we examine the distributions and extremes of surface air temperature and pressure in the Arctic for the late 20th century, using Alaskan weather station data, an atmospheric reanalysis, and general circulation models (GCMs). There is good agreement among these sources for the late 20th century, with broader distributions for both temperature and pressure in winter as compared to summer, and over land as compared to over ocean. We used the output from 21 st-century greenhouse simulations by the GCMs to address the occurrence of extremes in the coming decades. The model projections of the 21 st-century extremes largely agree with changes in the mean state, with record low temperatures decreasing in frequency and record high temperatures increasing in frequency. The changes in 21 st-century extremes are more pronounced over the ocean, where the present-day distributions are narrower. The projected decreases of mean pressure result in more frequent occurrences of extreme low pressure, especially over the Arctic Ocean, although the extremes of pressure are less affected by changes of the means than are the extremes of temperature. Lastly, we find that the transition from sea ice to open water, and associated changes in the salinity of the surface water, can cause changes in the temperature distribution that are more complex than simple shifts in the distribution, leading to unexpected changes in the occurrence of extreme temperatures.
\end{abstract}

Key words: Alaska, Arctic, climate, temperature, atmospheric pressure, extremes, thresholds, climate projections, climate models

RÉSUMÉ. Les changements en matière de températures et de pressions extrêmes dans l'Arctique reçoivent peu d'attention dans le contexte du changement climatique. Ici, nous examinons les répartitions et les extrêmes de la température de l'air en surface et de la pression dans l'Arctique vers la fin du XX $\mathrm{X}^{\mathrm{e}}$ siècle et ce, en nous appuyant sur les données de la station météorologique de l'Alaska, sur une nouvelle analyse atmosphérique et sur des modèles de circulation générale. Il existe une bonne concordance quant aux sources visant la fin du $\mathrm{XX}^{\mathrm{e}}$ siècle, avec des répartitions plus vastes pour les températures et pressions d'hiver comparativement à celles de l'été, ainsi que pour les températures et pressions terrestres par rapport aux températures et pressions océaniques. Nous nous sommes également servi des données émanant de simulations de serres au XXI siècle, réalisées au moyen des modèles de circulation générale afin d'être en mesure de nous pencher sur l'occurrence des extrêmes au cours des décennies à venir. Les projections de modèles relatives aux extrêmes du XXI siècle concordent largement avec les changements caractérisant l'état de la moyenne, la fréquence des basses températures record étant à la baisse et la fréquence des hautes températures record étant à la hausse. Les changements en matière d'extrêmes au $\mathrm{XXI}^{\mathrm{e}}$ siècle sont plus prononcés au-dessus de l'océan, là où les répartitions actuelles sont plus étroites. Les diminutions projetées de la pression moyenne se traduisent par des occurrences plus fréquentes de basses pressions extrêmes, surtout au-dessus de l'océan Arctique, bien que les extrêmes en matière de pressions soient moins touchés par les changements des moyennes que les extrêmes de températures. De plus, nous estimons que la transition allant de la glace de mer à l'eau libre, de même que les changements connexes du point de vue de la salinité de l'eau de surface, peuvent entraîner des changements sur le plan de la répartition des températures qui sont plus complexes que de simples décalages de répartition, ce qui mène à des changements inattendus en matière d'occurrence de températures extrêmes.

Mots clés : Alaska, Arctique, climat, température, pression atmosphérique, extrêmes, seuils, projections climatiques, modèles climatiques

Traduit pour la revue Arctic par Nicole Giguère.

\section{INTRODUCTION}

Extreme weather events such as high and low temperatures, heavy precipitation, droughts, floods, and highwind events can have large and immediate impacts on ecosystems, humans, and infrastructure. These impacts are often greater than those arising from modest changes in climatic means. One of the research needs identified in the Arctic Climate Impact Assessment (ACIA, 2005) was for more quantitative and credible determinations of the relationships between extreme events and changes of climatic means in the Arctic. The ACIA report based its evaluation of recent and projected changes almost entirely on averages over space (e.g., $60-90^{\circ} \mathrm{N}$ ) or time (seasons, years,

\footnotetext{
${ }^{1}$ Department of Atmospheric Sciences, 105 S. Gregory Street, University of Illinois, Urbana, Illinois 61801, USA

${ }^{2}$ Corresponding author: timlin@atmos.uiuc.edu

(C) The Arctic Institute of North America
} 

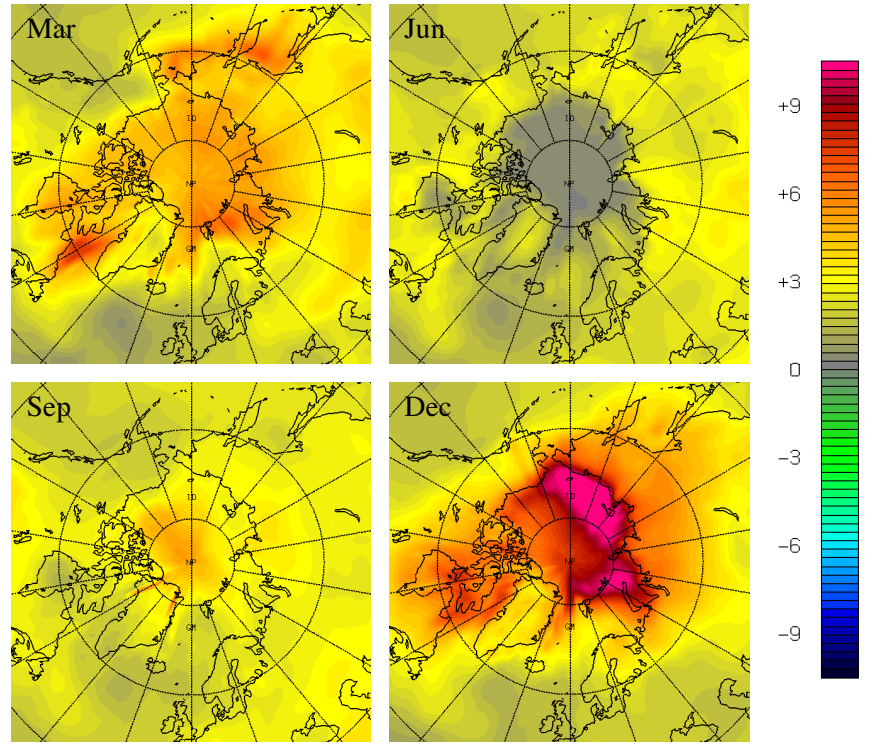

FIG. 1. Five-model composite view of change in mean surface air temperature from 1980-99 to 2070-89, for March, June, September, and December.

decades) or both. Such averaging inevitably obscures the extremes that may occur episodically over limited areas. Hence a systematic evaluation of ongoing and projected changes in extreme events in the Arctic is needed. The present paper provides a first look at model-derived distributions of daily surface air temperature and sea level pressure in the Arctic, both for the present climate and for projections over the 21 st century. The model simulations examined here are those used in the Arctic Climate Impact Assessment (ACIA, 2005).

As noted by past studies (e.g., IPCC, 2001), changes in mean temperature over the past several decades are relatively large in the Arctic region, and a polar amplification of temperature changes is a characteristic of projections of greenhouse-driven climate changes (Holland and Bitz, 2003). However, there is a strong seasonality in the spatial pattern of the projected warming. Figure 1 shows the fivemodel composite change of surface air temperature from the late 20th century to the late 21st century for March, June, September, and December, thus capturing the contrast in the seasonally varying projected warming. While the temperatures show widespread increases during all calendar months, the spatial patterns of the increases are strongly tied to the surface conditions, land or sea. In June, the largest increases are over land, with essentially no warming over the Arctic Ocean, although there are increases of temperature over the North Pacific and North Atlantic subpolar seas. The pattern of the trends is strikingly different in December, when the high-latitude warming is greater than in summer and shows a sharp poleward increase across the margin of the Arctic Ocean. The increases are significantly larger over the Arctic Ocean than over the other oceans and Arctic land masses.

The prominent changes in Arctic Ocean temperature are likely tied to large changes in ice extent over the Arctic
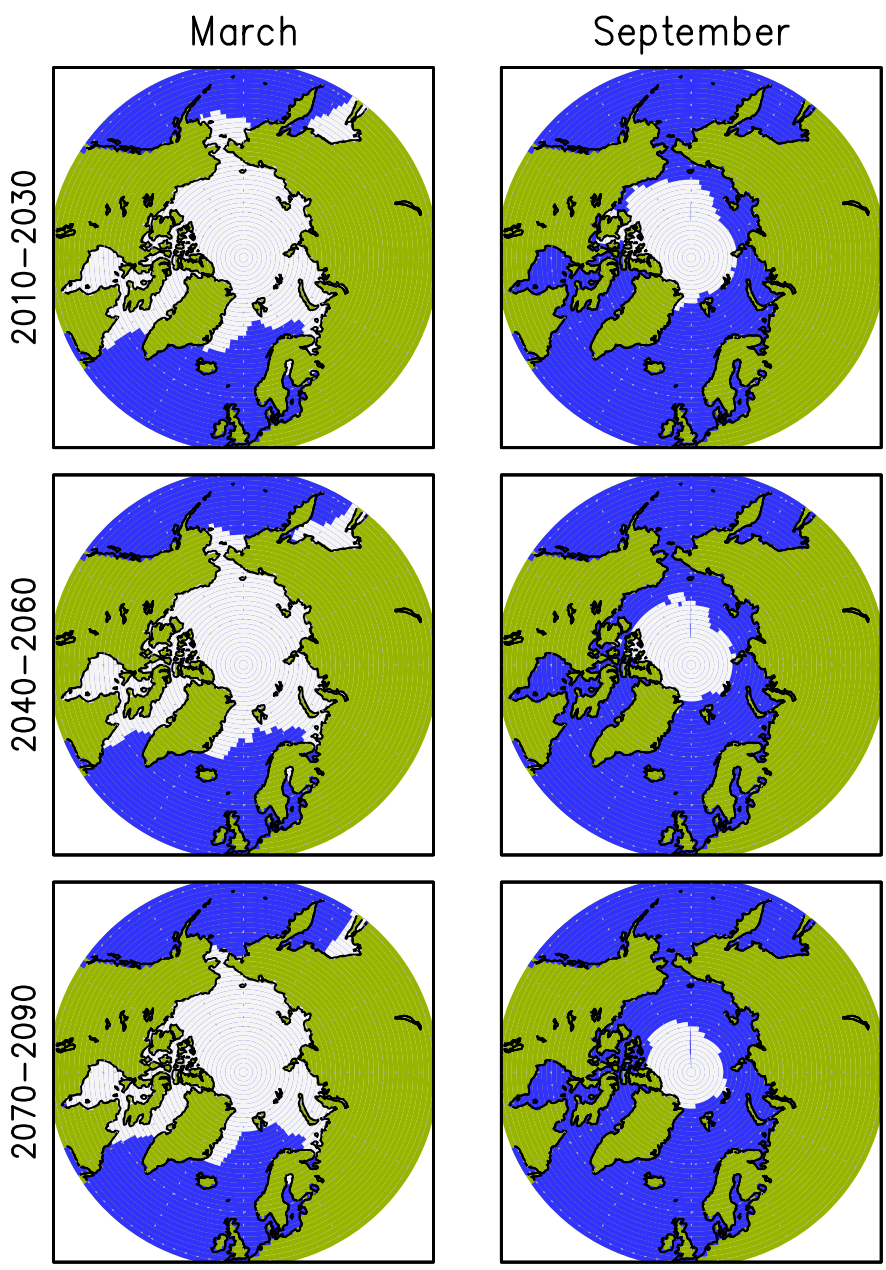

FIG. 2. Five-model composite view of median ice extent in March and September in 2010-30, 2040-60, and 2070-90.

Ocean in the 21st century. Model projections show decreasing ice extent, particularly at the time of the annual minimum in ice extent, which typically occurs in early September (Fig. 2). Exposed ocean surfaces are no colder than about $-1.8^{\circ} \mathrm{C}$ compared to much lower temperatures $\left(-30^{\circ}\right.$ to $\left.-40^{\circ} \mathrm{C}\right)$ over thick sea ice, so upward surface heat fluxes are much greater over open water and thin sea ice than over thick sea ice during autumn and winter. Consequently, changes in ice extent (along with changes in concentration and thickness) are closely related to changes in near-surface air temperature, at least during autumn and winter.

In the present paper, we examine variations in daily temperature and sea-level air pressure in the context of changes in mean climate such as those summarized above. Our objectives are (1) to assess the models' simulations of distributions of daily values and (2) to supplement information on changes in the means with data on changes in the extreme values, thereby adding to the information base for future impact studies. Particular foci of the evaluation described here are the relationships of changing extremes to season, to continentality (land vs. ocean), and to changes in the sea ice cover. 
TABLE 1. Information for the five models used in the ACIA.

\begin{tabular}{|c|c|c|}
\hline Abbreviation & Model & Reference \\
\hline $\mathrm{CCC}$ & Canadian Climate Centre for Modeling and Analysis, version CGCM2 & Flato et al., 2000 \\
\hline CSM & Climate System Model, National Center for Atmospheric Research, version CSM1.4 & Boville et al., 2001 \\
\hline $\mathrm{ECH}$ & European Centre/Hamburg, Max-Planck Institute, version ECHAM4/OPYC3 & Roeckner et al., 1999 \\
\hline GFD & Geophysical Fluid Dynamics Laboratory, Version GFDL-R30_c & Knutson et al., 1999 \\
\hline HAD & Hadley Centre for Climate Prediction and Research, version HadCM3 & Gordon et al., 2000 \\
\hline
\end{tabular}

\section{DATA AND MODEL OUTPUT}

We use three different data sets in this study. The first data are the daily output (temperature and pressure) from the five models, listed in Table 1, that make up the ACIA archive. The available daily variables are summarized in Table 2.

The climate model output used here was obtained from the ACIA model archive. While the reliance on this source resulted in some constraints on the available output, it provided the advantage of a consistent set of model simulations that had been pre-screened for Arctic applications. In particular, the resolutions, vintages (i.e., "model generation"), and greenhouse forcing were similar among all the models. These five models were pre-selected by an ACIA scenarios group (Källén et al., 2001) because all are well documented in the refereed literature, have participated in major international model intercomparison projects, and have had their Arctic results analyzed and published (e.g., Walsh et al., 2002). While more recent model results have become available, their inclusion in this study would have been at the expense of the heterogeneity and pre-screening that characterized the set of five ACIA-designated models.

The CSM model had the most extensive set of archived variables, including a full set of temperature variables (daily mean, maximum, and minimum temperatures) and two measures of pressure, surface pressure (PS) and sealevel pressure (SLP). The CCC model archive included a full set of temperature variables as above. For the ECH and GFD models, daily mean temperature was the only temperature variable available. SLP was available for ECH and PS for GFD. The HAD archive provided daily maximum and minimum temperatures. We derived a mean daily temperature by averaging these values for each day. Although maximum and minimum temperatures were available for only three of the models, we found that these variables showed results very similar to those of the daily mean temperature, with one exception that we will discuss later in the paper.

Three models have daily output of a pressure variable, either sea-level pressure or surface pressure. The former is obtained from the latter by a downward extrapolation using an assumed lapse rate of temperature. Because the CSM has both pressure variables, we were able to make a comparison between them. The two pressure values were the same over the oceans and nearly identical over low-
TABLE 2. Availability of daily output from the ACIA models. Tmean, Tmax and Tmin refer to the daily mean, maximum, and minimum temperatures; SLP denotes sea level pressure; and PS denotes surface pressure.

\begin{tabular}{lccccc}
\hline \hline Model & Tmean & Tmax & Tmin & SLP & PS \\
\hline CCC & $\mathrm{X}$ & $\mathrm{X}$ & $\mathrm{X}$ & & \\
CSM & $\mathrm{X}$ & $\mathrm{X}$ & $\mathrm{X}$ & $\mathrm{X}$ & $\mathrm{X}$ \\
ECH & $\mathrm{X}$ & & & $\mathrm{X}$ & $\mathrm{X}$ \\
GFD & $\mathrm{X}$ & & $\mathrm{X}$ & & \\
HAD & derived & $\mathrm{X}$ & & & \\
\hline \hline
\end{tabular}

lying land areas, but (not surprisingly) they showed large differences over elevated land areas. However, we found that the choice of the pressure variable had no discernible impact on conclusions about temporal variations at a given location. We therefore used both pressure variables together in obtaining our "all-model" pressure results.

The second source of information consists of Alaskan weather station observations for the 20th century. These data, obtained from the National Climatic Data Center (NCDC), include daily maximum and minimum temperatures for observing stations with varying periods of record. In this study, we used the full record available to help avoid issues from shorter periods. Using the station data for only 1980-99 (not shown) gave similar but noisier results. Our use of these data focused on three Alaskan stations in very different climatic regimes: Barrow (194999) on the northern coast of Alaska, Nome (1949-99) on the west coast, and McGrath (1942-99) in the interior. The elevation of McGrath is $102 \mathrm{~m}$. Each station was chosen to represent its climate regime because the data quality and quantity were good over a long period, and because populations of these communities were small enough that effects of urbanization should be insignificant, in contrast to larger Alaskan cities such as Anchorage and Fairbanks.

The third source of information was the gridded temperature and pressure output from the recent reanalysis of the European Centre for Medium-Range Weather Forecasts (ECMWF). This reanalysis, known as ERA-40, is described by Uppala et al. (2005). The four-times-daily output was averaged to create daily grids. The reanalysis data were examined both for specific grid points, to compare to the station data, and for areal averages, to compare to the corresponding average values from the model projections. 


\section{Barrow}
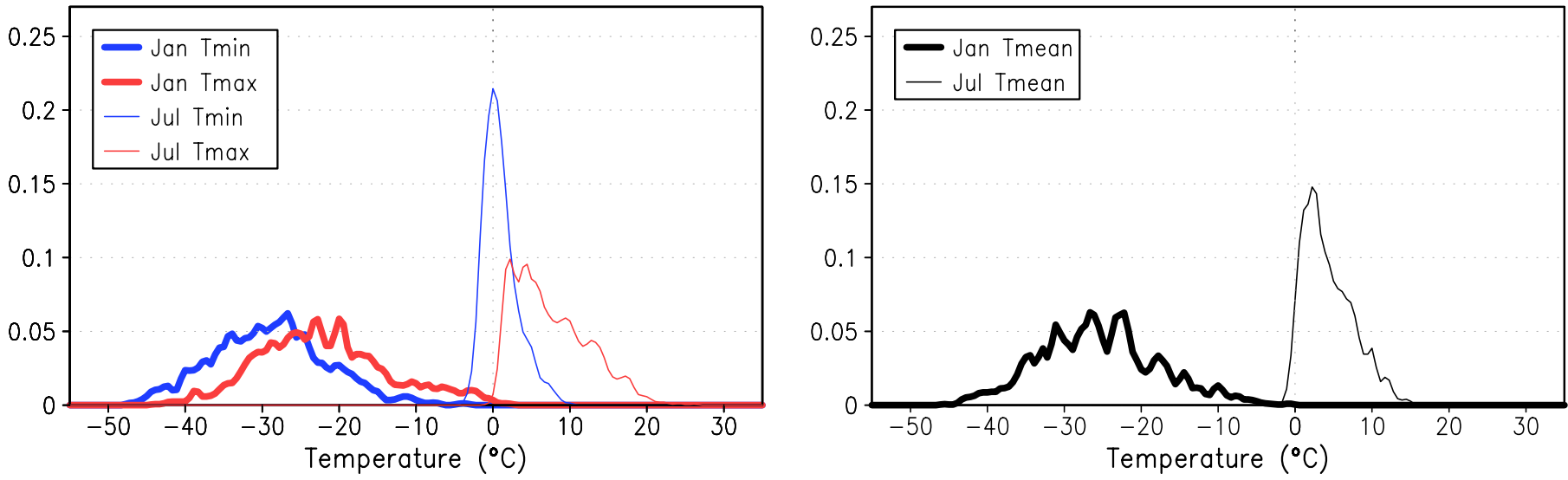

Nome
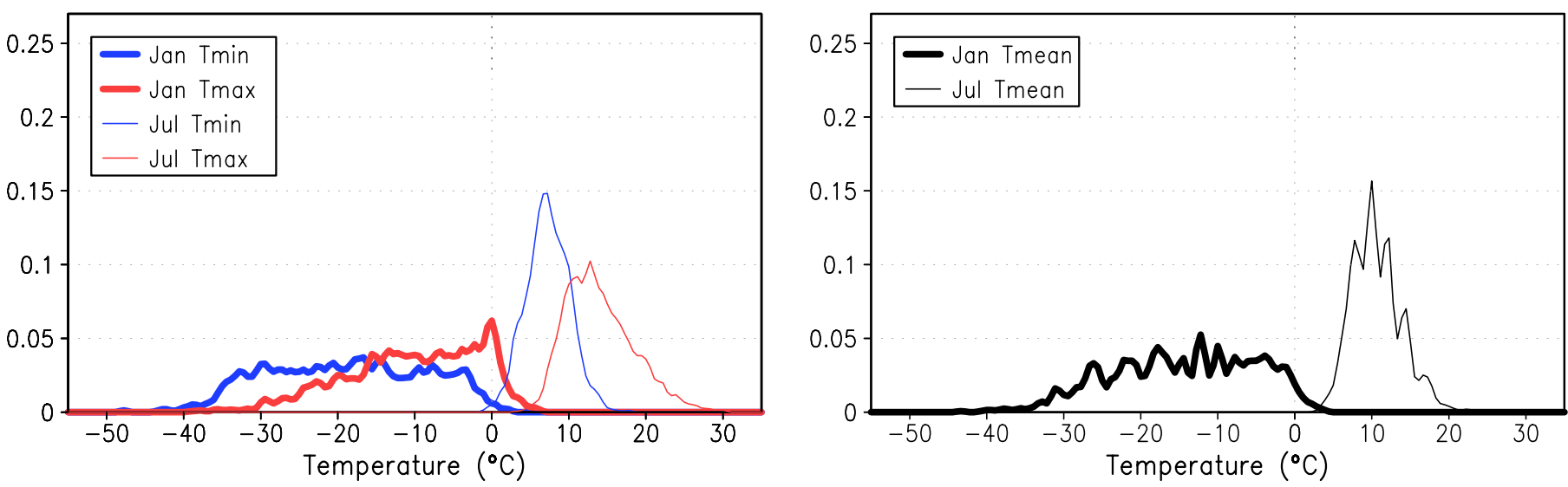

McGrath
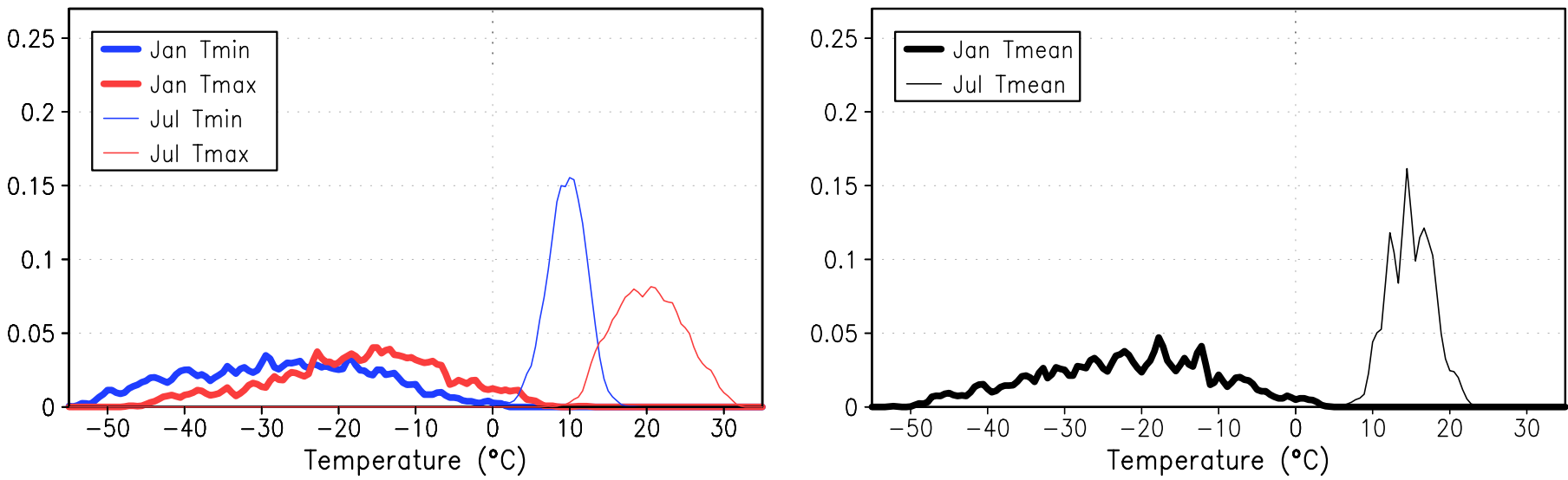

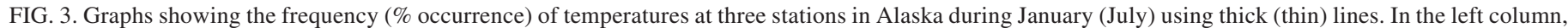

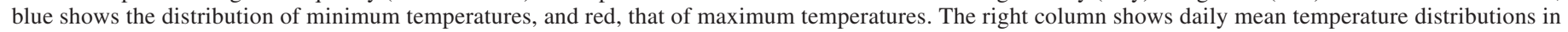
black. Calculations were done using bins of $1^{\circ} \mathrm{F}$ (five-ninths of a degree Celsius) with the area under the curve equal to unity.

\section{RESULTS}

\section{Present Climate}

In order to illustrate the observed variations of daily quantities, Figure 3 shows the distributions of observed temperatures from the three stations in Alaska. The left panels of Figure 3 contain the graphs of both minimum (blue) and maximum (red) temperatures for January (thick) and July (thin) for Barrow, Nome, and McGrath. In addition, graphs of mean daily temperature (the average of the daily maximum and minimum temperatures) are shown (black lines) in the right panels of Figure 3 for January and July. Values on the y-axis in all panels represent the percentage of total observations, for that variable and month falling within a range of five-ninths 
of a degree Celsius $\left(1.0^{\circ} \mathrm{F}\right)$ and centered on the integer value $\left({ }^{\circ} \mathrm{F}\right)$ of the archived station data. This temperature resolution, dictated by the reporting and archival of station observations in ${ }^{\circ} \mathrm{F}$, is used consistently throughout the present paper. The January graphs in Figure 3 have peaks that are broader and lower than those for July. This is expected, as temperatures vary more during winter at most locations that experience seasonal variations. The distributions of minimum temperature and maximum temperature are more similar in January than in July. The difference between minimum and maximum temperature in July is most notable at Barrow, where a strong peak in minimum temperatures occurs near $0^{\circ} \mathrm{C}$, as the influence of the nearby open water of the Arctic Ocean constrains minima to remain near the freezing point. Temperatures at Nome are similarly influenced by the water temperatures in the Bering Sea. The lower peaks for all stations in July maximum temperature as compared to peaks for July minimum temperature can also be attributed to the larger impact of clouds on maximum temperature variation in the summer, leading to a broader distribution of maximum temperature.

The plots of mean daily temperature in Figure 3 allow us to compare the distribution of temperature at the stations with the distributions of temperature for grid points in the ERA-40 reanalysis. Because the ERA-40 has sixhourly archived output, which is insufficient to determine maximum and minimum temperatures, we averaged the four values to get a measure of daily mean temperature. The nearest grid points were chosen for comparison with Nome and McGrath. For Barrow, the nearest ERA-40 grid point is north of the station and thus over the ocean. Therefore a grid point slightly more distant from Barrow, to the south and over land, was used for comparison with the Barrow observations. Results for the selected grid points in the ERA-40 are shown as brown lines in Figure 4 for both actual temperatures (left panels) and anomalies (departures from climatological means, right panels). The black lines show station data results from the right panels of Figure 3 for direct comparison. Not unexpectedly, there are slight differences in the graphs of mean daily temperature between the station data (black) and the ERA-40 data (brown) in the left panels of Figure 4, as the model does not fully represent the orography and local effects that shape the station data. For January, the ERA-40 model results are very similar to the station data results in the mean, range, shape, and amplitude of the distribution. For July, the ERA-40 results are similar to the observational data for McGrath and Nome, but for Barrow the graphs show a lower and broader peak that encompasses warmer temperatures than the station data. The shape of the distribution of station data for Barrow is influenced by the nearby open water of the Arctic Ocean, which leads to a large, steep drop-off in the graph as the temperature drops below zero. The July ERA-40 mean temperatures for Barrow extend to $20^{\circ} \mathrm{C}$, while the station data mean temperatures extend only to $12^{\circ} \mathrm{C}$ (in fact, even the maximum tempera- tures for the station data extend only to $20^{\circ} \mathrm{C}$ ). Again, this difference indicates that the maritime influence is not fully captured by the grid-cell mean of the ERA-40 reanalysis. The increased distance to the coast from the ERA-40 grid point likely accounts for part of this discrepancy.

The use of anomalies (Fig. 4, right panels) rather than actual temperatures is necessary in order to create regional averages over an area where the mean temperatures vary. Such area-averaging is justified by the similarities of the plots shown on the right hand side of Figure 4. If one were to create multi-location graphs of actual temperatures (e.g., from the left panels of Fig. 4), the result would be a misleadingly broad distribution, whereas the plots based on temperature anomalies are not broadened by the spatial variation in mean temperatures. The upper panel of Figure 5 shows a summary graph (shaded) of the temperature anomalies for each grid cell over Alaska $\left(60-70^{\circ} \mathrm{N}, 165-140^{\circ} \mathrm{W}\right)$ that closely resembles the plots for selected grid cells from Figure 4 (shown as lines in Fig. 5). The peak and range of the January and July graphs over Alaska (shaded) match the results from Figure 4 (lines in Fig. 5). Even when using anomalies, the aggregation of various grid cells can lead to a broadening of the distribution as a result of differences in variance and skewness, but this broadening effect is not apparent in our study.

Over the ocean, the available station data from Arctic buoys have limitations due to the changes of buoy locations and to exposure problems. The latter arise because the instrument is housed inside a buoy, and the buoy itself occasionally becomes buried in snow (Rigor et al., 2000; Chen et al., 2002). The similarities between the ERA-40 and station-derived graphs for land areas suggest that one may effectively use the reanalysis-derived temperature anomalies over an area of the Arctic Ocean. The distributions of ERA-40 temperatures for an ocean area (75$85^{\circ} \mathrm{N}, 165-140^{\circ} \mathrm{W}$ ) are shown in the lower panel of Figure 5. The July anomalies have a narrow distribution that peaks higher than the Alaskan distributions in the upper panel (half as wide, twice as high), indicating that there is less variability over the ocean than over land. Similarly, for January, there is a narrower and higherpeaking distribution for the ocean than for land, again suggesting that the underlying ocean exerts a constraining influence via heat fluxes through areas of open water (leads) and thin ice. Additionally, there is a slight difference in the skewness in January, with the highest peak (mode) at about $3^{\circ} \mathrm{C}$ over land and near $0^{\circ} \mathrm{C}$ over ocean.

Figure 6 shows the corresponding distributions of SLP from the ERA-40 for the same regions used in Figure 5. The variability of SLP is also greater in January than in July. For SLP, the seasonal difference is larger over land than over ocean, whereas temperature showed similar seasonal differences over land and ocean. The skewness displayed in January SLP anomalies over Alaska (mode value $\sim-5 \mathrm{mb}$ ) and over the ocean (mode value $\sim-2 \mathrm{mb}$ ) is likely due to the most extreme values' creating an especially long tail for high SLP, as was the case for the 
ERA-40 near Barrow $\left(70.0^{\circ} \mathrm{N}, 157.5^{\circ} \mathrm{W}\right)$
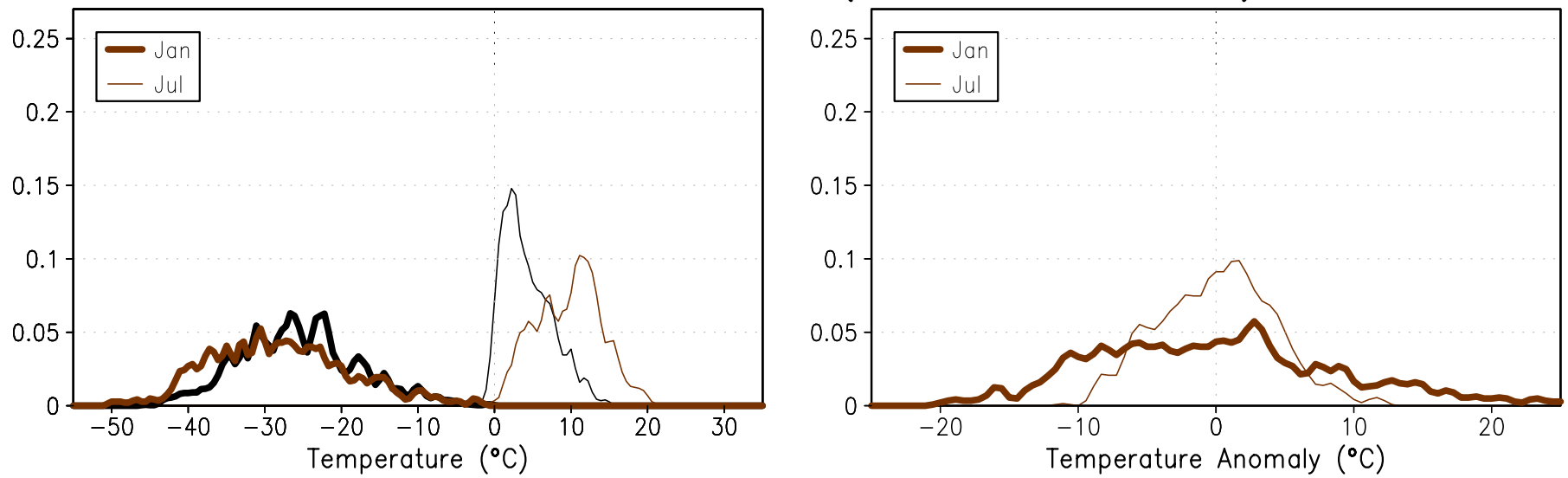

ERA-40 near Nome

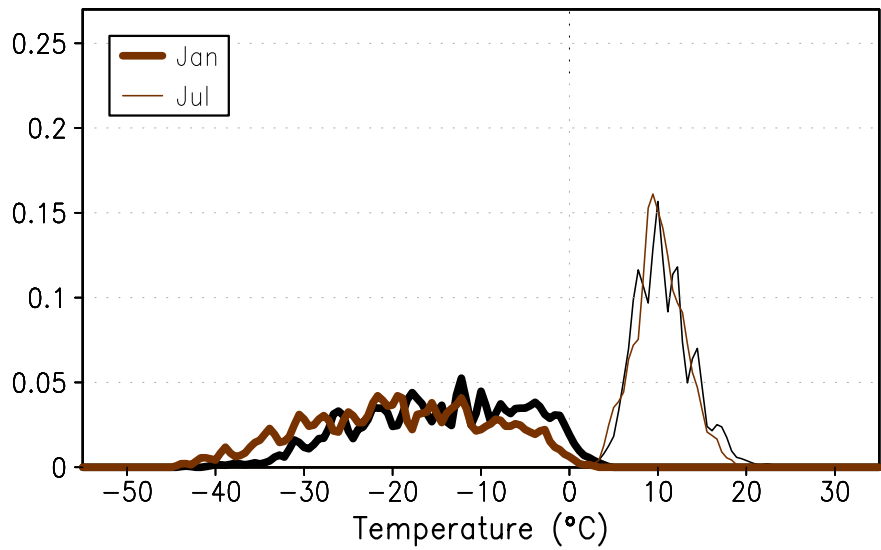

$\left(65.0^{\circ} \mathrm{N}, 165.0^{\circ} \mathrm{W}\right)$

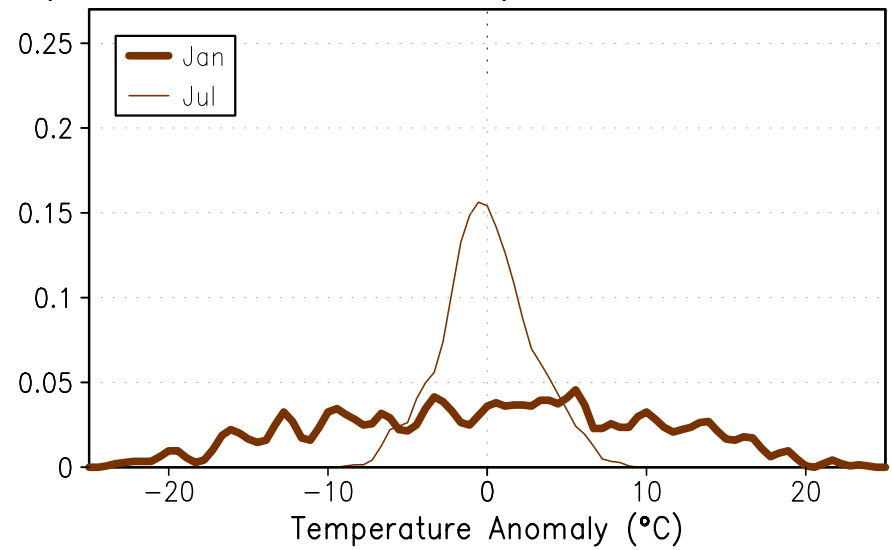

ERA-40 near McGrath $\left(62.5^{\circ} \mathrm{N}, 155.0^{\circ} \mathrm{W}\right)$
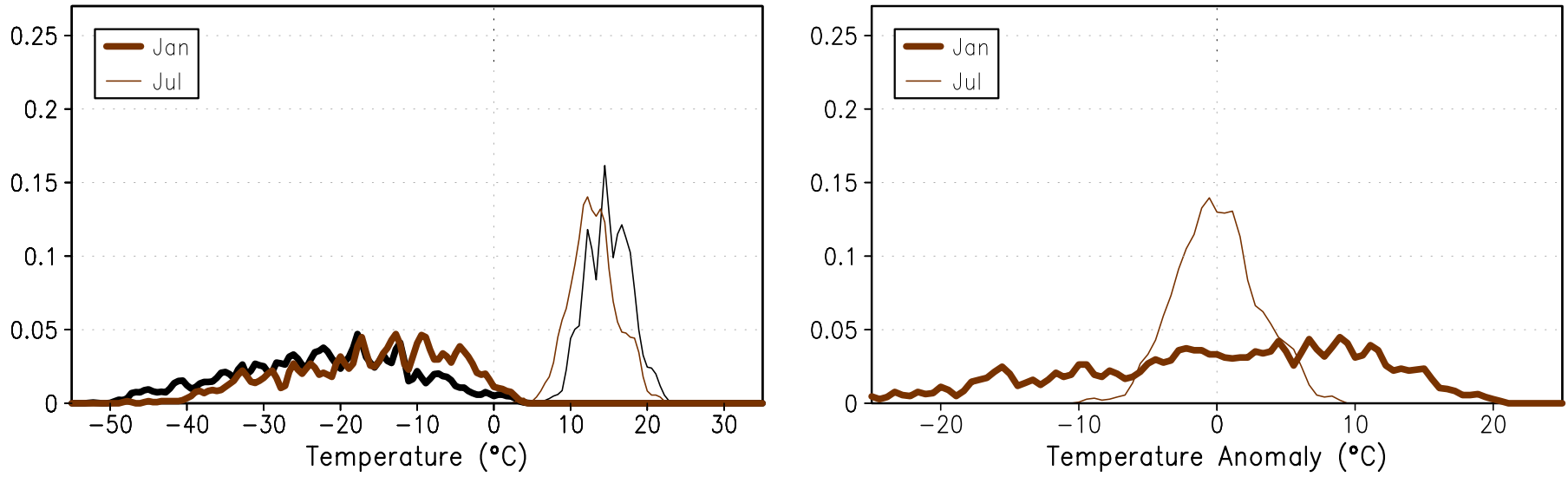

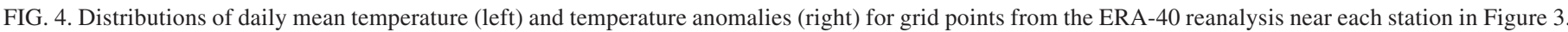

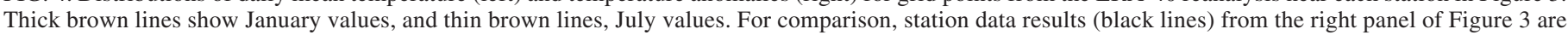
repeated on the left panel of this figure.

long tail of negative temperature anomalies over Alaska (mode values $\sim 3^{\circ} \mathrm{C}$ ). This is consistent with the results of Holzer (1996).

Figure 7 and Figure 8 show the ACIA model-derived distributions of temperature and pressure corresponding to Figures 5 and 6. Over land, both the temperature and pressure distributions from all five models (lines) are similar among the models and to the ERA- 40 results (shaded). Over the ocean, however, there are some differences among the models. The January temperatures over the ocean from the CCC model more closely resemble the temperatures over land than is the case in the other models. For the July temperatures, all the ACIA models (lines) have a much narrower distribution (note the different scale on this panel) than the ERA-40 results (shaded). This discrepancy leads to very high relative frequencies near 

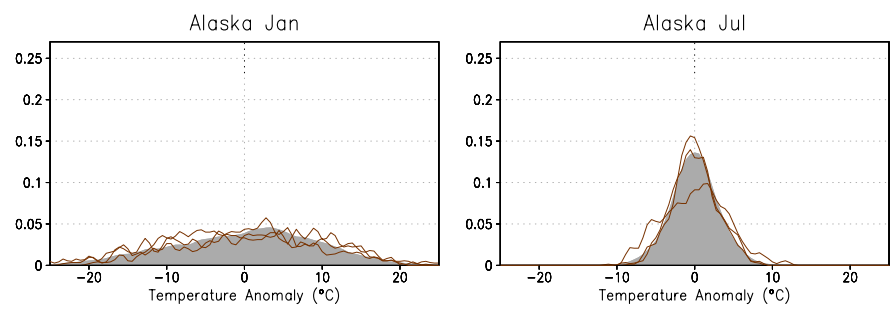

Arctic Ocean Jan
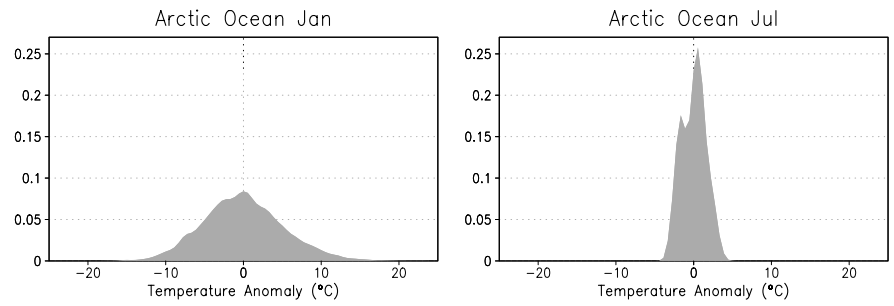

FIG. 5. Shading shows the distribution of daily temperature anomalies accumulated over Alaska $\left(60-70^{\circ} \mathrm{N}\right.$ and $\left.165-140^{\circ} \mathrm{W}\right)$ and a region of the Arctic Ocean $\left(75-85^{\circ} \mathrm{N}\right.$ and $\left.165-140^{\circ} \mathrm{W}\right)$ for January and July using ERA40 reanalysis data. For comparison, the Alaska panels also show lines representing the ERA-40 data at station locations from Figure 4.
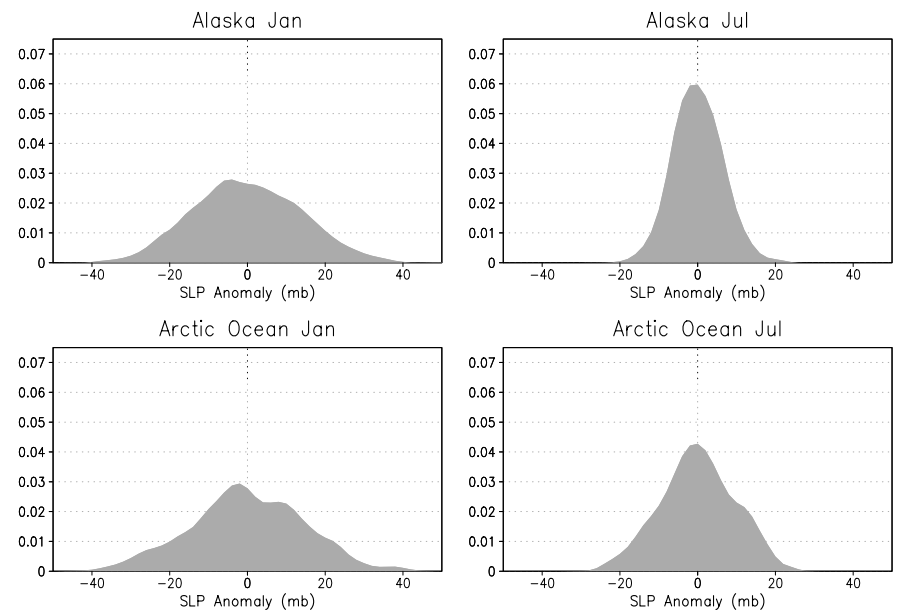

FIG. 6. Distribution of sea level pressure (SLP) for Alaskan and Arctic Ocean sectors defined in Figure 5. Calculations were done using bins of $2 \mathrm{mb}$.
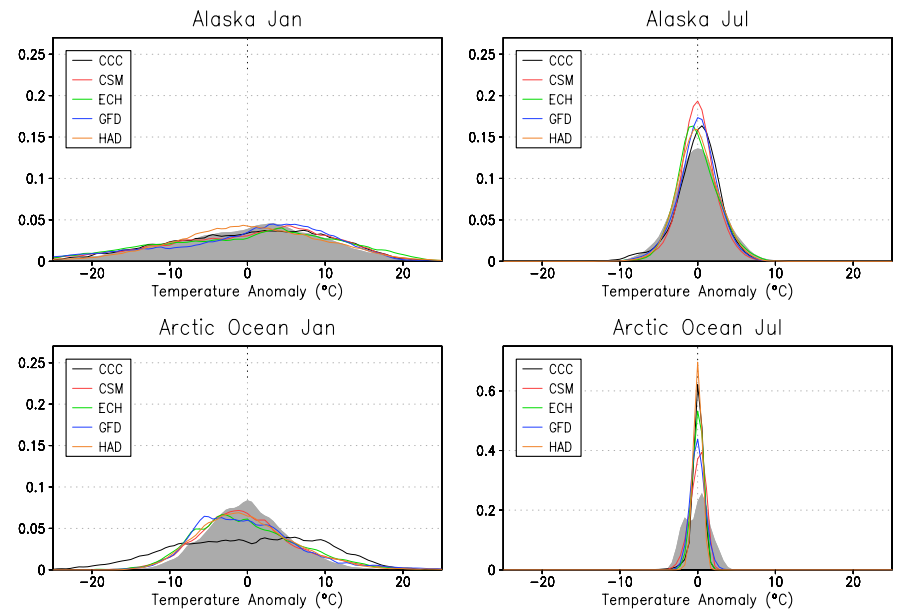

FIG. 7. Distribution of temperature anomalies for Alaska (upper) and Arctic Ocean (lower) sectors from five ACIA models (colored lines). The shading shows the ERA-40 results from Figure 5 for comparison. Note that for July, the Arctic Ocean scale has been altered to accommodate the larger data values.
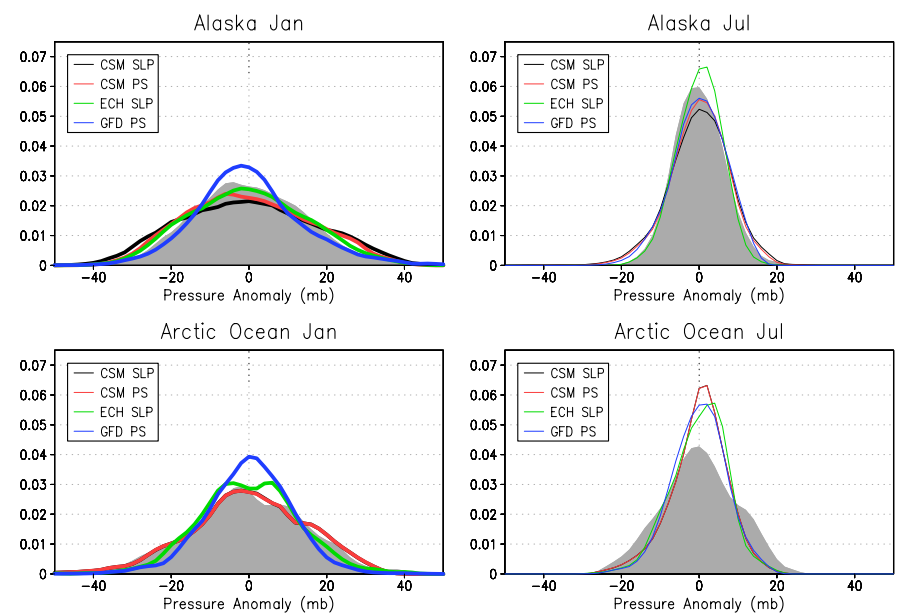

FIG. 8. Distribution of pressure anomalies for Alaska (upper) and Arctic Ocean (lower) sectors from five ACIA models (colored lines). Shading shows results from Figure 6 for comparison.

the means, indicating that the ACIA model results are too tightly constrained to the ocean surface temperature. For pressure, the agreement between the ACIA models (lines) and ERA-40 (shaded) over the ocean is good, as the only notable discrepancy is a slightly narrower and higher peak of the models' distributions in July. Over the ocean, SLP and PS are by definition identical, so the CSM SLP and CSM PS curves overlap completely, and only one line is visible in the bottom panel of Figure 8.

The general agreement of the results for Alaskan station data, model reanalysis, and GCM projections indicates that the models capture the primary characteristics of the distributions. This general agreement suggests that the model results can be used to extend the analysis to 21 stcentury projections of the ACIA models and to assess the tendency for extreme values to change in future decades.

\section{Projections for the 21st Century}

We used the 21 st-century simulations from each ACIA model to evaluate the projected changes, for each grid point, in the number of values falling outside the same model's corresponding range for 1980-2000. We refer to the highest and lowest of the 21 values for a particular grid point and calendar date as "thresholds" for possible exceedence in future time slices. In other words, the thresholds are the daily "record highs" and "record lows" for the period 1980-2000. For a 21-year sample, the chance-level for achieving an anomalous value this large (or larger) on a particular calendar date, in the absence of a systematic change in the distribution, is $1 / 21$. For consistency, the future time slices examined here are also 21 years in duration: 2010-30, 2040-60, and 2070-90. The ratio of the projected number of exceedences (values outside the 1980-2000 thresholds) to the number expected by chance can be determined either for single grid points or for areas (such as the ocean and land regions in Fig. 9). To calculate this ratio, we first summed each set 


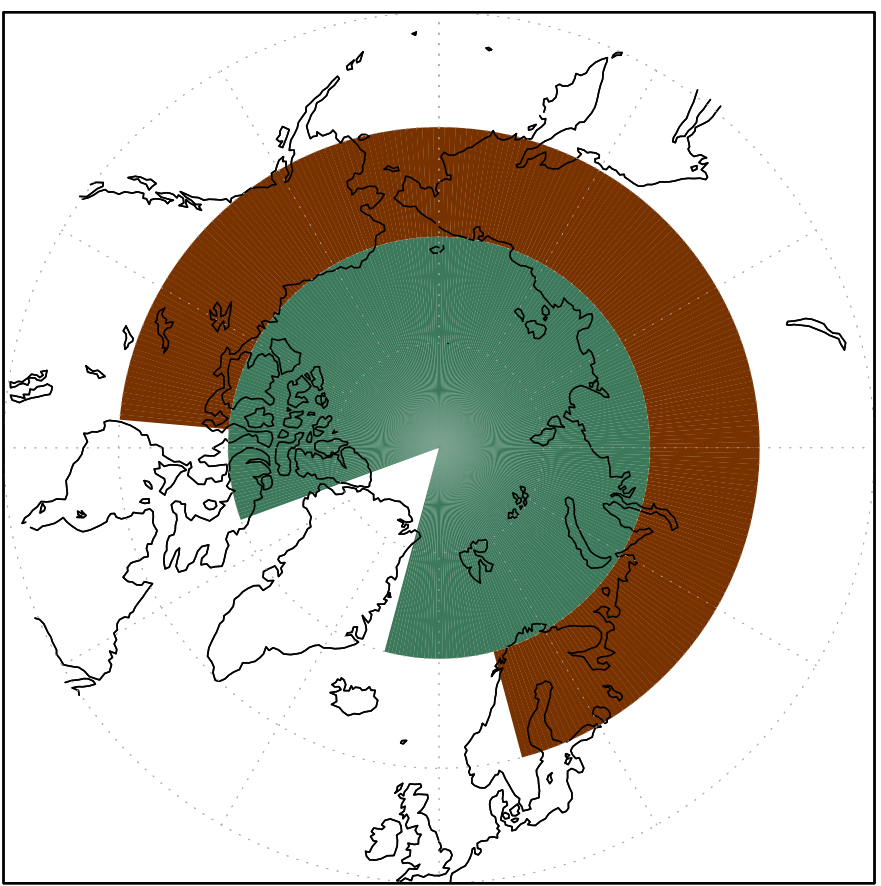

FIG. 9. Land-sea mask used for ACIA model projections for the 21 st century. The land is brown and covers the area from $60^{\circ}$ to $70^{\circ} \mathrm{N}$ and from $15^{\circ}$ to $265^{\circ}$ E. Sea is green and covers the area from $70^{\circ}$ to $90^{\circ} \mathrm{N}\left(15^{\circ} \mathrm{W}\right.$ to $\left.290^{\circ} \mathrm{E}\right)$.

of threshold exceedences over a period of time (a month, season, or year) to smooth out some of the sampling variability inherent in the use of daily records with limited cases. Then we compared the sums of projected and expected exceedences. A ratio of 1.0 indicates that the projected number of exceedences is equal to the expected number (based on 1980-2000 occurrences). Ratios larger than 1.0 indicate an increase in threshold exceedences compared to the expected number, and those smaller than 1.0 , a decrease.

The use of a 21-member group to define the thresholds for a given day and grid point is subject to large sampling uncertainties. However, the ACIA archives of daily model output are limited to 21 -year time slices. Although the uncertainty of results for specific days and grid points is high, the uncertainty is much lower when the results are examined in aggregations over a large number of days and grid points, as is done here. In an attempt to approximate this uncertainty and its reduction through aggregation, we looked at the percentage of data expected to be beyond the extreme values, assuming a normal distribution with the same mean and variance observed for 1980-2000. We found that the expected percentage beyond the extremes varies considerably for a given day and grid point, but when examined in aggregate this expected percentage matches closely to the nominal expected value $(1 / 21)$. Therefore, although our nominal expected value would introduce uncertainty to the results if we were to look at specific days or grid points, this expected value is adequate for the aggregate results.

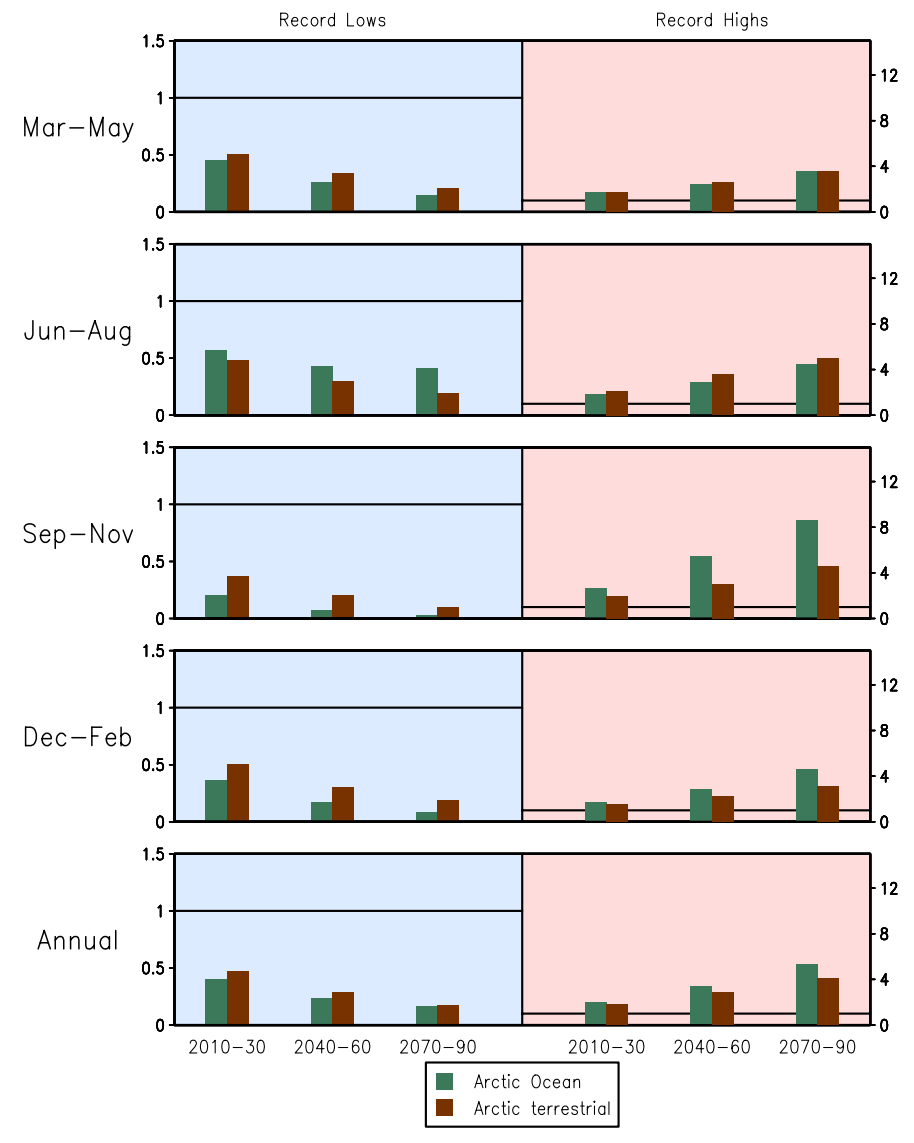

FIG. 10. Daily mean temperature exceedence results for all five models, expressed as ratios of projected to expected exceedences of 1980-2000 ranges. Left panels show record lows, and right panels, record highs, for the Arctic Ocean and land regions defined in Figure 9, for each three-month period and the annual total, and for three 21-year periods in the 21st century archived for the ACIA study.

The ocean and land regions were each chosen to encompass primarily one surface type (ocean or land), to be simple in shape, to be roughly equal in size, and to avoid Greenland, where the topography of the ice sheet makes model results less credible. A more rigorous assignment of land or ocean based on the land mask of the model gave similar results (not shown), but it introduced complications due to the differences in land mask and model resolution among the models. Here, the output of each model is used on its native grid, and grid points are assigned only to the land and ocean region in which they are located. The number of grid points that constitute the land or ocean area thus varies from model to model, but the prescribed area remains the same across models. Because we are using results only for the large areas defined in Figure 9, the disparate resolutions do not require a regridding to a common grid and the associated problems that might introduce.

Figure 10 presents the exceedence statistics for mean daily temperature, showing composite results of all five ACIA models. Low exceedences (record lows) are on the left, and high exceedences (record highs), on the right. Note that different scales are used on left and right y-axes 

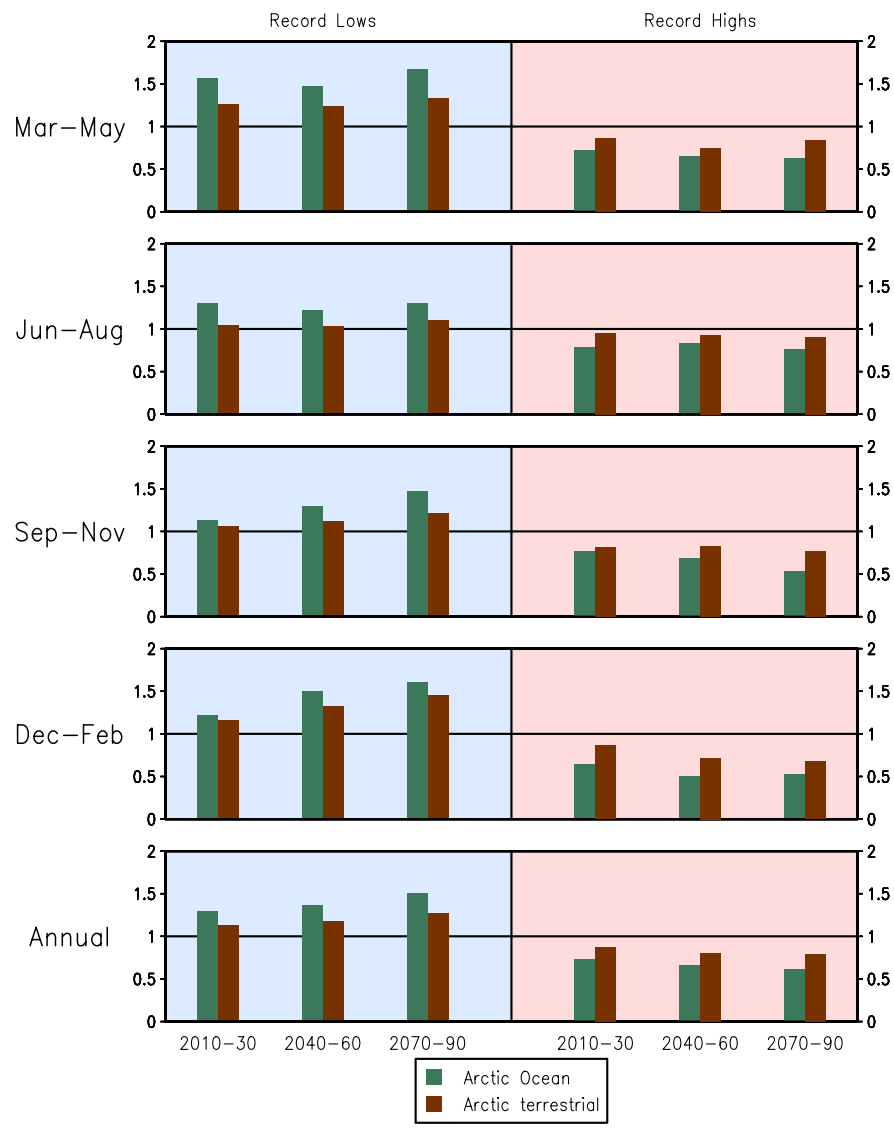

FIG. 11. Daily mean pressure exceedence results for the three models with available pressure output. Details are as in Figure 10.

to better display the changes. Results for the land areas (brown) and ocean areas (green) defined in Figure 9 are shown here for each season and for the annual average (panels from top to bottom) and for each future time slice (bars from left to right in each panel). Each bar represents a ratio of simulated exceedences to chance-level exceedences, as described above.

The overall trend is generally consistent among the time slices and seasons, with decreasing frequencies of record low and increasing frequencies of record high temperatures as the 21 st century progresses. The record low temperatures monotonically decrease in each season, with greater decreases over the ocean compared to land in each season except summer (June-Aug). In summer, record lows over both land and ocean decrease in frequency, and in contrast to the other seasons and the annual results, the decrease is stronger over land. The upward trends of record high temperatures are larger over the ocean for each season except spring and summer, which show slightly larger increases in record highs over land. The results over land are similar throughout the seasons, while the results over ocean show a more pronounced seasonal cycle. The trend in high temperatures is largest in autumn. The general character of these results is consistent with the temperature change shown in Figure 1, and also with a shift in the distribution of temperatures rather than a change in the shape of the
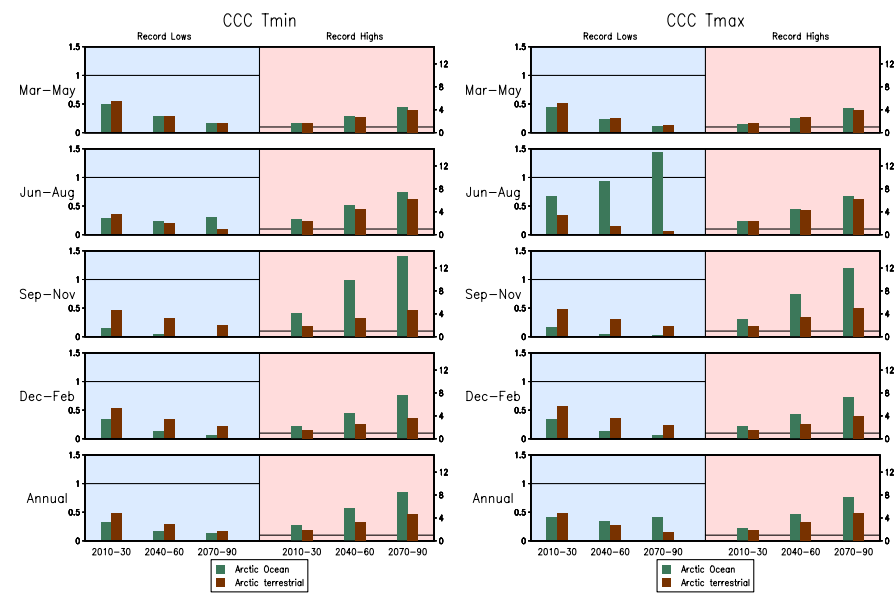

FIG. 12. Maximum and minimum temperature exceedence results from the CCC model. Details are as in Figure 10.

distribution, although the results presented here do not rigorously prove this contention. The results suggest that ratios of actual and expected exceedences, summed over time and space as we have done here, can be inferred from changes in the mean values, at least for the Arctic.

Figure 11 shows the projected changes of extremes of sea level pressure. While the results are shown in the same format as Figure 10, they are based on only the three models for which a pressure variable, either sea level or surface pressure, was available. Again, a generally consistent change is apparent, with increases in record low pressure and decreases in record high pressure. Although the pressure changes are consistent in sign, they do not show as strong a trend over the 21 st century as the temperatures do. The trend throughout the century is monotonic in some seasons (e.g., autumn) but not in others (e.g., spring). Changes in pressure are larger over the ocean than over land in all seasons and eras. The tendency toward lower pressure for the Arctic Ocean is consistent with the warming trend in surface temperature and could imply more numerous or more intense storms.

The plots for mean daily temperatures in individual models (not shown) are similar to the composite in Figure 10, although with differences of detail in the amplitude of the change, the difference between land and sea, and seasonality. Similarly, daily maximum and minimum temperature results for a given model largely mirror the results for mean daily temperature in that model. One notable exception was maximum temperature in the CCC model, for which the minimum and maximum temperature results are shown in Figure 12. The changes of minimum temperature are similar to those of the mean daily temperature for this model, with very large ratios, especially in the fall. Maximum temperature results are consistent with minimum temperature results in all cases except for the summertime record lows of maximum temperature over the ocean. In this case, record lows of maximum temperature over the ocean do not decrease as sharply as the record lows of minimum temperature for 2010-30. In subsequent 

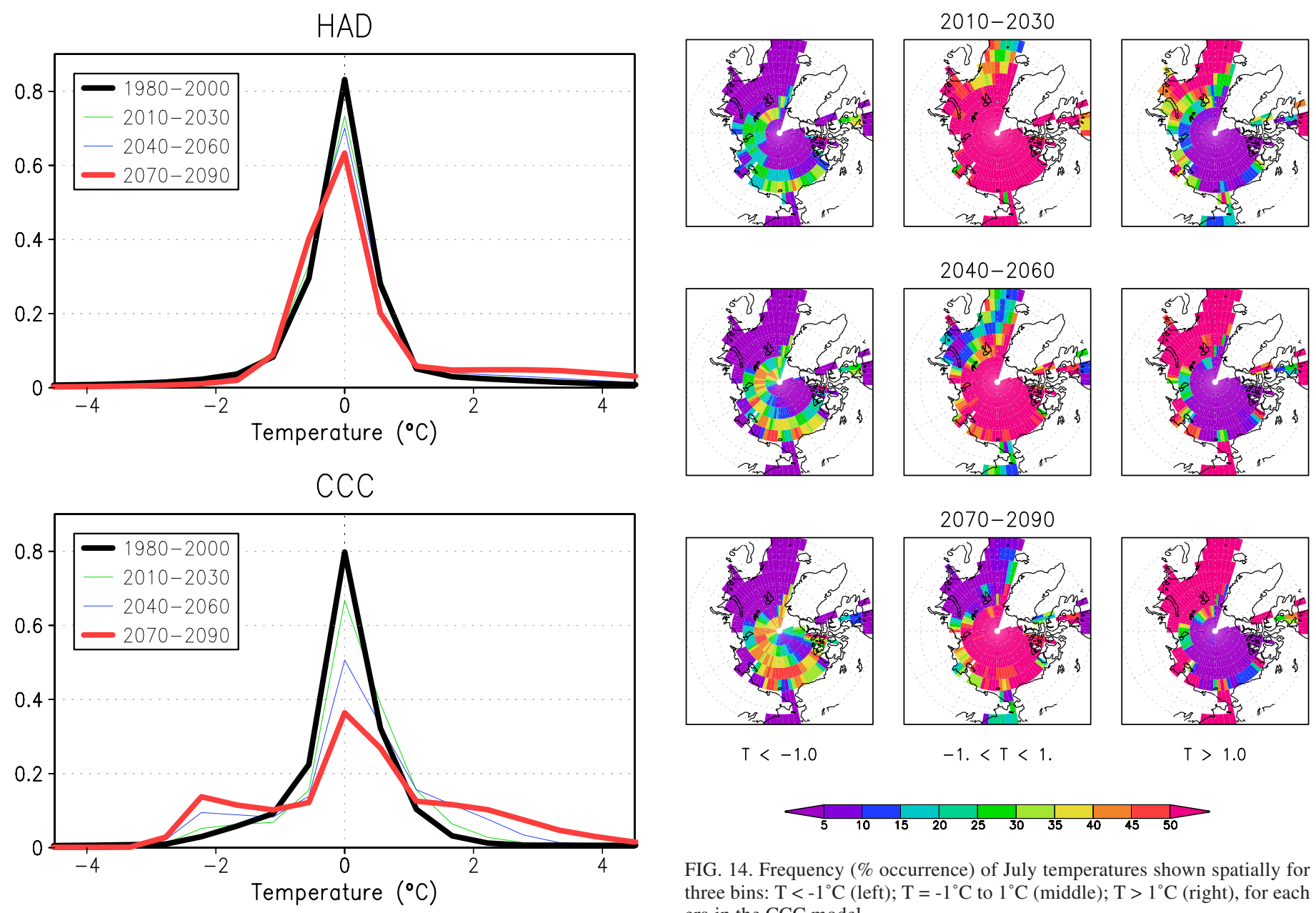

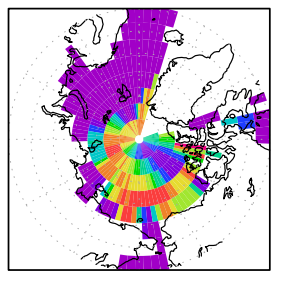

$T<-1.0$

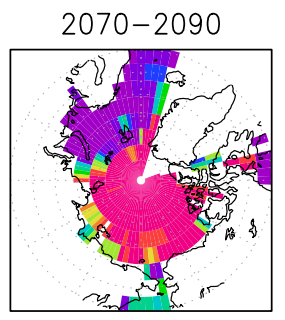

$-1 .<T<1$

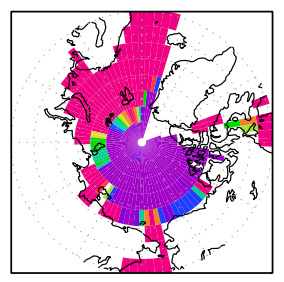

$\mathrm{T}>1.0$

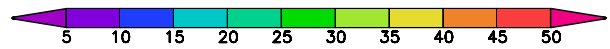

FIG. 14. Frequency (\% occurrence) of July temperatures shown spatially for three bins: $\mathrm{T}<-1^{\circ} \mathrm{C}$ (left); $\mathrm{T}=-1^{\circ} \mathrm{C}$ to $1^{\circ} \mathrm{C}$ (middle); $\mathrm{T}>1{ }^{\circ} \mathrm{C}$ (right), for each era in the CCC model.

FIG. 13. Distributions of July temperatures projected by the HAD and CCC models over the Arctic Ocean, for four 20-year time slices. Calculations were done using bins of $1^{\circ} \mathrm{F}$ (five-ninths of a degree Celsius).

time slices, the ratio for the record low maximum temperature increases: there are more record low maximum temperatures than expected by chance. This appears inconsistent with climate warming and with the results over land, with the results for minimum temperatures, and even with the record highs of maximum temperature over the ocean. In this case, the ratios for maximum temperature increase for both record highs and record lows. Because the HAD model also shows a subtle lack of decrease in record low maximum temperature over the 21 st century, we examined HAD and CCC to determine the cause. Figure 13, which shows the distributions of actual (not anomalous) July maximum temperatures for $\mathrm{CCC}$ and HAD, in a similar format to Figure 5, indicates that over time there is a slight broadening of the HAD distribution and a subtle shift to colder temperatures near zero. These changes lead to the decrease in frequency of occurrence of temperatures around $0^{\circ} \mathrm{C}$ and the increase for temperatures around $-1^{\circ} \mathrm{C}$. In addition, there is also a decrease in the tails of the distribution for values less than $-1^{\circ} \mathrm{C}$ and an increase for values greater than $1^{\circ} \mathrm{C}$ in HAD. It is the increased occurrence of temperatures around $-1^{\circ} \mathrm{C}$ that accounts for

the slight increase in record low Tmax in HAD. In contrast, the increase of record lows of July maximum temperature is quite different in $\mathrm{CCC}$, where temperatures around $0^{\circ} \mathrm{C}$ show a large decrease with time, while there is a large increase in temperatures between $1^{\circ} \mathrm{C}$ and about $5^{\circ} \mathrm{C}$. This increase corresponds to the greater frequency of record high maximum temperatures. However, there is also an increase in temperatures of around $-2^{\circ} \mathrm{C}$, so that a secondary maximum is created in the distribution where none existed in the 1980-2000 results. It is this secondary maximum that leads to the increase in record low Tmax in CCC.

By examining the ratios of record low temperatures spatially, for each grid point over the Arctic Ocean (not shown), we were able to determine the likely cause of the secondary peak around $-2^{\circ} \mathrm{C}$. In general, the narrow temperature peaks at $0^{\circ} \mathrm{C}$ over the ocean are consequences of the surface state, which is typically a mix of melting ice and fresh water from melt at the surface during the summer. The secondary peak near $-2^{\circ} \mathrm{C}$ indicates that in later time slices, when most of the summer ice has disappeared, the surface conditions are constrained by very cold saline water rather than by fresh water, as the melting point of salty ocean water is around $-1.8^{\circ} \mathrm{C}$. In order for this to be the case, there would need to be a lack of ice to melt, as is 
$2010-2030$

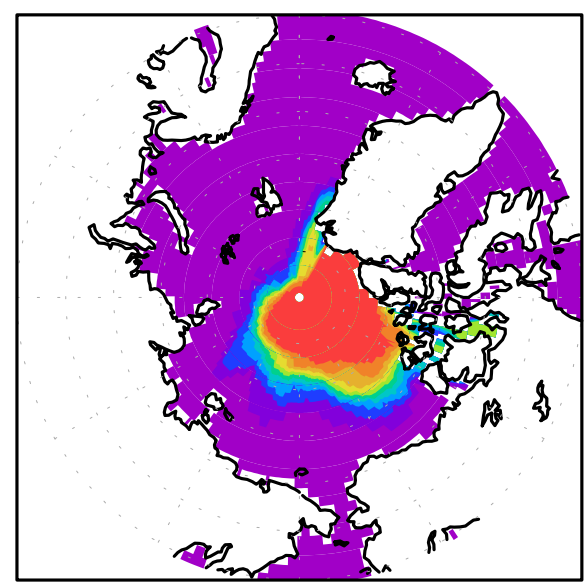

$2040-2060$

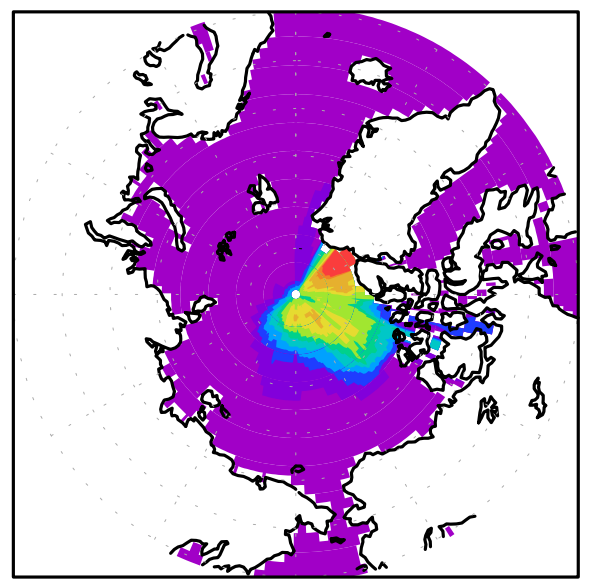

$2070-2090$

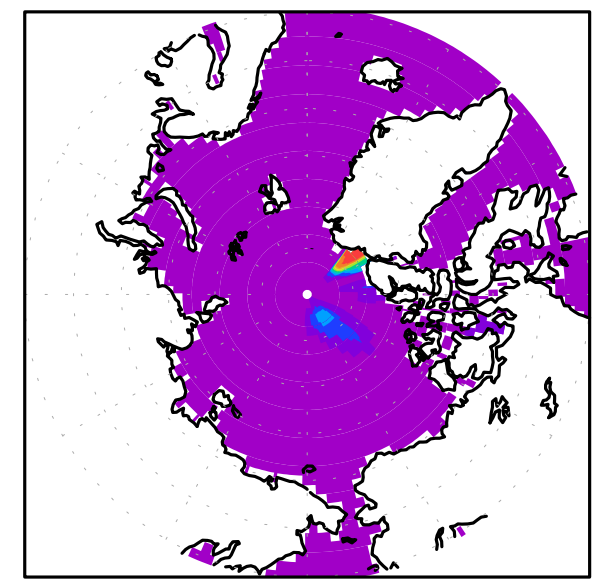

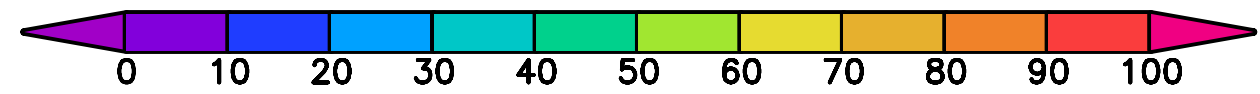

FIG. 15. Percentage of years with ice in August projected by the CCC model for 2010-30 (left), $2040-60$ (middle), and 2070-90 (right).

indeed the case in the later years of the simulation by the CCC model, which in summer starts with less ice and then loses ice at a faster rate over the 21 st century than any of the other models in this study (ACIA, 2005: Chapter 6).

Figure 14 shows frequencies (\%) of the July maximum temperatures in the $\mathrm{CCC}$ model for each ACIA time slice grouped into three bins: $\mathrm{T}<-1{ }^{\circ} \mathrm{C}$ (left), $\mathrm{T}=-1{ }^{\circ} \mathrm{C}$ to $1{ }^{\circ} \mathrm{C}$ (middle), and $\mathrm{T}>1{ }^{\circ} \mathrm{C}$ (right). The sum of the frequencies in the three bins is $100 \%$ for each time slice at each grid point. The warmer colors indicate higher frequencies of occurrence. In the area north of Europe, where the increase in record maximum temperature occurs, there is a shift over time from temperatures in the middle bin to temperatures in the warmest bin. To the north of eastern Siberia and Alaska, there is very little increase in the warmer bin. Instead, occurrences in the colder bin in this area show an increase in frequency at the expense of the middle bin. There is an area of purple (minimal frequency of occurrence) for $\mathrm{T}<-1^{\circ} \mathrm{C}$ in each time slice that matches well spatially to the location of August sea ice in the CCC model (Fig. 15) for that time slice. The evolution of the temperature extremes shown in Figure 13 for $\mathrm{CCC}$ is consistent with the increasing occurrences of temperatures around $-2^{\circ} \mathrm{C}$ in areas away from the lingering summer ice in the $\mathrm{CCC}$ simulation, while temperatures continue to be constrained to around $0^{\circ} \mathrm{C}$ near those areas with lingering ice.

\section{CONCLUSIONS}

The results presented here show that there is generally good agreement between the distributions of daily temperature and pressure values in observational data, the ERA-40 reanalysis, and simulations by the global climate models used in the Arctic Climate Impact Assessment. The primary disagreements appear to be associated with coastal resolution and the spatial averaging inherent in grid-cell means.

The distributions of daily values of temperature and pressure are much broader in winter than in summer. This finding extends across all variables (daily mean, daily maximum and daily minimum temperatures, sea level pressure, and surface pressure) and across all information sources (station observations, ERA-40, and the ACIA climate models).

The distributions of daily temperature are generally narrower over the oceans than over land areas, especially when the ocean constrains the maximum temperature as it does in summer. GCMs exaggerate this summer constraint beyond what is observed in the real world.

Model projections of 21 st-century changes in the distributions of temperature and pressure extremes are generally consistent with the projected changes in the corresponding mean values. Extreme low temperatures are projected to decrease in frequency, while extreme high temperatures are projected to increase in frequency. Annually, the projected decrease in record lows is monotonic. The projected decrease of record low temperatures and the increase of record high temperatures are greater over the ocean than over land in each season except summer. In summer, record low temperatures over both land and ocean decrease in frequency, but the trend is stronger over land. The larger changes of extreme values over the ocean are consistent with the narrower present-day distributions over the ocean, making the ranges easier to exceed by changes of a specific magnitude.

The transition from sea ice to open water can be a dominant factor in determining the changes in extreme temperature. Because the melting of ice constrains the air 
temperatures (e.g., in the present-day summer climate), the disappearance of sea ice and the associated changes in ocean salinity (freezing temperature) lead to complex and subtle changes in the distribution of temperature.

Changes in mean pressure do not alter the occurrence of extreme pressures as much as changes in mean temperature affect the extreme temperatures in the 21 st-century model simulations. In general, the projected decreases of mean pressure imply more extreme low pressure occurrences. However, the changes of extreme pressure evaluated here cannot be unambiguously tied to changes in cyclones and anticyclones because pressure centers are defined in relation to surrounding values of pressure.

Future work will focus on the relation between changing extremes of pressure and temperature. The linkage between these variables is provided by the atmospheric circulation, for which the changes of spatial patterns of pressure become important. The extent to which changes of extreme temperature are determined by changes in atmospheric circulation (temperature advection) or by local heating will establish the importance of the temperature-pressure linkage in the attainment of new extremes of temperature.

Future work will also focus on the exceedence of specific thresholds of temperature, especially thresholds with human and ecological consequences. The present study indicates that daily values obtained from the ERA-40 reanalysis and even global climate models can provide valuable information about extremes in data-sparse areas such as the Arctic, and can therefore supplement direct measurements in assessments of threshold exceedences relevant to humans and ecosystems.

\section{ACKNOWLEDGEMENTS}

The authors thank William Chapman for his help in making the ACIA model projections available. This work is supported by the National Science Foundation's Office of Polar Programs through grant OPP 05-20112.

\section{REFERENCES}

ACIA. 2005. Arctic climate impact assessment: Scientific report. Cambridge: Cambridge University Press. 1042 p.

BOVILLE, B.A., KIEHL, J.T., RASCH, P.J., and BRYAN, F.O. 2001. Improvements to the NCAR CSM-1 for transient climate simulations. Journal of Climate 14(2):164-179.

CHEN, Y., FRANCIS, J.A., and MILLER, J.R. 2002. Surface temperature of the Arctic: Comparison of TOVS satellite retrievals with surface observations. Journal of Climate 15(24):3698-3708.

FLATO, G.M., BOER, G.J., LEE, W.G., McFARLANE, N.A., RAMSDEN, D., READER, M.C., and WEAVER, A.J. 2000. The Canadian Centre for Climate Modelling and Analysis global coupled model and its climate. Climate Dynamics 16(6): $451-467$.

GORDON, C., COOPER, C., SENIOR, C.A., BANKS, H., GREGORY, J.M., JOHNS, T.C., MITCHELL, J.F.B., and WOOD, R.A. 2000. The simulation of SST, sea ice extents and ocean heat transports in a version of the Hadley Centre coupled model without flux adjustments. Climate Dynamics 16(2-3): $147-168$.

HOLLAND, M.M., and BITZ, C.M. 2003. Polar amplification of climate change in coupled models. Climate Dynamics 21(34):221-232.

HOLZER, M. 1996: Asymmetric geopotential height fluctuations from symmetric winds. Journal of the Atmospheric Sciences 53(10): $1361-1379$.

IPCC (INTERGOVERNMENTAL PANEL ON CLIMATE CHANGE). 2001. Climate change 2001: The scientific basis. Contribution of Working Group I to the Third Assessment Report of the Intergovernmental Panel on Climate Change. Edited by J.T. Houghton, Y. Ding, D.J. Griggs, M. Noguer, P.J. van der Linden, X. Dai, K. Maskell, and C.A. Johnson. Cambridge and New York: Cambridge University Press. 881 p.

KÄLLÉN, E., KATTSOV, V., WALSH, J., and WEATHERHEAD, E. 2001. Report from the Arctic Climate Impact Assessment Modeling and Scenarios Workshop. 29-31 January 2001, Stockholm, Sweden. 34 p.

KNUTSON, T.R., DELWORTH, T.L., DIXON, K.W., and STOUFFER, R.J. 1999. Model assessment of regional surface temperature trends (1947-1997). Journal of Geophysical Research 104(D24):30981-30996.

RIGOR, I.G., COLONY, R.L., and MARTIN, S. 2000. Variations in surface air temperature observations in the Arctic, 1979-97. Journal of Climate 13(5):896-914.

ROECKNER, E., BENGTSSON, L., FEITCHTER, J., LELIEVELD, J., and RODHE, H. 1999. Transient climate change simulations with a coupled atmosphere-ocean GCM including the tropospheric sulfur cycle. Journal of Climate 12(10):3004-3032.

UPPALA, S.M., KÅLLBERG, P.W., SIMMONS, A.J., ANDRAE, U., da COSTA BECHTOLD, V., FIORINO, M., GIBSON, J.K., HASELER, J., HERNANDEZ, A., KELLY, G.A., LI, X., ONOGI, K., SAARINEN, S., SOKKA, N., ALLAN, R.P., ANDERSSON, E., ARPE, K., BALMASEDA, M.A., BELJAARS, A.C.M., van de BERG, L., BIDLOT, J., BORMANN, N., CAIRES, S., CHEVALLIER, F., DETHOF, A., DRAGOSAVAC, M., FISHER, M., FUENTES, M., HAGEMANN, S., HÓLM, E., HOSKINS, B.J., ISAKSEN, L., JANSSEN, P.A.E.M., JENNE, R., McNALLY, A.P., MAHFOUF, J.-F., MORCRETTE, J.-J., RAYNER, N.A., SAUNDERS, R.W., SIMON, P., STERL, A., TRENBERTH, K.E., UNTCH, A., VASILJEVIC, D., VITERBO, P., and WOOLLEN, J. 2005. The ERA-40 re-analysis. Quarterly Journal of the Royal Meteorological Society 131:2961-3012.

WALSH, J.E., KATTSOV, V.M., CHAPMAN, W.L., GOVORKOVA, V., and PAVLOVA, T. 2002. Comparison of Arctic climate simulations by uncoupled and coupled global models. Journal of Climate 15(12):1429-1446. 